\title{
86505 - DIRETIVAS ANTECIPADAS E AUTONOMIA DO IDOSO
}

\author{
Pôster - Gerontologia
}

Caroline Oliveira da Silva / Silva, CO / PUCRS; Anelise Crippa / Crippa, A / PUCRS; Marcelo Bonhemberger / Bonhemberger, M / PUCRS

Considerando o crescimento da população idosa no contexto mundial e que a questão do envelhecimento também preocupa o fim da vida, visa a bioética tratar as diretivas antecipadas de vontade em seu modelo principialista. Desta forma, à luz dos princípios do respeito à autonomia, justiça, beneficência e não-maleficência analisa-se a finitude do idoso de forma autônoma e justa. O objetivo do presente trabalho é analisar as diretivas antecipadas de vontade sob o prisma dos princípios bioéticos. Para a realização deste trabalho foi feito uma análise da Resolução 1.995/12 do Conselho Federal de Medicina, bem como da doutrina que embasa o principialismo bioético. Ademais, foi feita uma busca em artigos publicados com a temática de idoso/gerontologia/geriatria e as diretivas antecipadas/testamento vital, nas bases de dados SciELO, Google Acadêmico e Biblioteca Virtual em Saúde (BVS) que comporta bases de dados como LILACS e BDENF. Pode-se perceber que a Diretiva Antecipada de Vontade é a expressão máxima do princípio do respeito à autonomia. Com ela, a vontade do paciente terminal que não mais consiga se manifestar, fica preservada. Para tanto, será necessário que a pessoa, enquanto lúcida e capaz, realize a sua diretiva e leve à conhecimento de alguém (procurador), para que se cumpra, posteriormente, sua vontade. Os idosos, são a parcela da sociedade que, por estarem mais perto da finitude, devem ter ciência da existência das diretivas e usá-las, para que sua vontade prevaleça.

Palavras-chave: Idoso. Gerontologia. Diretivas Antecipadas.

Referências: BEAUCHAMP, T.L. \& CHILDRESS, J.F. Princípios de Ética Biomédica. (4 ed.) São Paulo: Edições Loyola, 2002. BRASIL. Conselho Federal de Medicina. Resolução no 1.995 de 9 de agosto de 2012. Disponível em: < http://www.portalmedico.org.br/resolucoes/ CFM/2012/1995_2012.pdf>. Acesso em: 01 jul 2019. DADALTO, Luciana. Testamento Vital. 3. ed. São Paulo: Atlas, 2015. FELIX, F.; KIRSTEN, K.; BONHEMBERGER, M. .Bioética, dignidade e o cuidado necessário em relação à terminalidade da vida. REVISTA DA SORBI, v. 5, p. 02-18, 2017. GOMES, B.M.M.; SALOMAO, L.A.; SIMOES, A.C.; REBOUCAS, B.O.; DADALTO, Luciana; BARBOSA, M.T. .Diretivas antecipadas de vontade em geriatria. Revista Bioetica - Conselho Federal de Medicina, v. 26, p. 429-439, 2018. PACHECO, B.; CRIPPA, A.; OLIVEIRA, P.O.. TESTAMENTO VITAL: a proteção da autonomia de vontade do paciente em casos de doenças terminais. REVISTA DA SORBI, v. 4, p. 58-78, 2016. 